\title{
THE EPIDEMIOLOGY OF ACUTE VIRAL GASTROENTERITIS IN HOSPITALIZED CHILDREN IN CORDOBA CITY, ARGENTINA: AN INSIGHT OF DISEASE BURDEN
}

\author{
Miguel O. GIORDANO(1), Leonardo J. FERREYRA(1), María B. ISA(1), Laura C. MARTINEZ(1), Silvia I. YUDOWSKY(2) \& Silvia V. NATES(1)
}

\begin{abstract}
SUMMARY
Information concerning the disease burden of viral gastroenteritis has important implications for the use and monitoring the impact of public health policies.

The present study, carried out in Córdoba city, Argentina, documents the epidemiology of severe viral diarrhea as well as the burden of viral gastrointestinal disease in the hospital children admission. A total of 133 stools were collected from hospitalized children (Town Childhood Hospital) suffering from acute diarrhea and studied for the presence of Group A rotavirus, astrovirus and adenovirus 40/41 by enzyme-immuno assay, between November 1997 and October 1998. Enteric viruses accounted for $42.1 \%$ of the total diarrheal cases analyzed. Group A rotaviruses, astroviruses, adenoviruses 40/41 and mixed infections were found in 35.3, 4.5, 1.5 , and $0.8 \%$ studied specimens respectively. We estimated that 1 in 27 children in the 0-35 month-old cohort/range would be annually hospitalized for a viral gastroenteritis illness. The major impact on viral diarrhea lies on rotaviral infection, accouting for $84.0 \%$ of the viral diarrheal cases analyzed and for approximately one third of severe diarrheas requiring hospital admission in Córdoba City, Argentina.
\end{abstract}

KEYWORDS: Viral diarrhea; Children inpatients; Rotavirus; Astrovirus; Enteric adenovirus; Argentina.

\section{INTRODUCTION}

Paediatric diarrhea remains one of the major causes of death among infants. This is especially true in Asia, Africa and Latin America, where it causes millions of deaths within the age group of 0 to 4 years. The main factors for high occurrence and mortality rate are: unsafe water, inadequate sanitation, and/or physiological conditions such as malnutrition. Besides, other physiologic events as weaning conferred an additional risk related to increased exposure to pathogens and decreased passively acquired immunity from breast milk. The immediate causes are often of an infectious nature and include a variety of pathogenic micro-organisms. Several different groups of viruses have been responsible for the high rate of acute viral diarrheal condition among children during their first few years of life. Rotavirus is one of the most prevalent and serious clinical agents. It is associated, with 30 to $50 \%$ of all cases of severe diarrhea in young children and aproximately with one third of diarrhea hospital admissions, contributing to 800,000 deaths per year worldwide ${ }^{18}$. Astrovirus has only recently been recognized as a common cause of diarrhea in children. The recent development and use of molecular methods and enzyme inmunoassays (EIA) to detect astrovirus led to report prevalences between 2.5 to $9 \%$ of astroviral infection among patients hospitalized with diarrhea ${ }^{7}$. A limited number of adenovirus strains have been cause-related to childhood diarrhea, namely only two distinct serotypes of adenovirus, types 40 and 41 , have been currently identified in the stool of infants and young children with gastroenteritis. Enteric adenovirus 40/41, has a global distribution associated with 4 to $10 \%$ of paediatric diarrhea in hospital inpatients and clinic out patients ${ }^{11}$.

Routine data and medical assistance on hospital admissions for diarrhea, combined with virological laboratory reports should be used to reinforce the surveillance of viral diarrhea. This may contribute to assess information about the epidemiology and disease burden of viral gastroenteritis more accurately.

Specific information based on laboratory data about the occurrence of illness and hospitalization due to viral gastroenteritis in Latin America is limited.

The present study, carried out in the Town childhood Hospital of Córdoba City, Argentina, examined the annual occurrence, relative frequencies and seasonal distribution of rotavirus, astrovirus and enteric adenovirus 40/41 in hospitalized children with acute gastroenteritis. These results of a hospital-based study allowed, by extrapolation of data, to

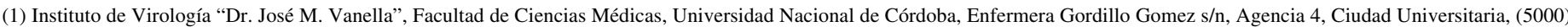
Córdoba, Argentina.

(2) Hospital Infantil Municipal, Municipalidad de la Ciudad de Córdoba, Jujuy 3300, (5000) Argentina.

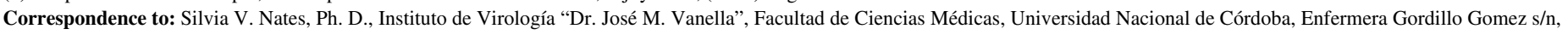
Agencia 4-Ciudad Universitaria, 5000 Córdoba, Argentina. Tel (54-351) 433-4022, Fax(54-351) 468-8272. e-mail: snates@cmefcm.uncor.edu 


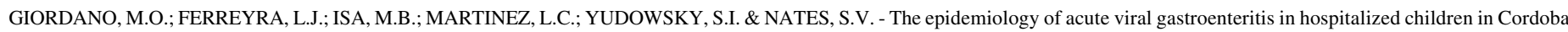
city, Argentina: an insight of disease burden. Rev. Inst. Med. trop. S. Paulo, 43(4):193-197, 2001.

estimate the annual viral diarrheal disease burden in the hospital children admission in Córdoba City, Argentina.

\section{MATERIALS AND METHODS}

Geographic localization: Córdoba is the capital city of the inland province of Córdoba. Its population of $\sim 1,168,000$ inhabitants rank second to Capital Federal (Capital city of Argentina) as the most important capital city from Argentina.

Study Subjects: The study was carried out at the Town Childhood Hospital, in Córdoba city, which assists approximately $41 \%$ of the Cordobezan pediatric population. This hospital receives children who require hospital admissions. All of them are referred from a network of 82 public health care centers from around all the Cordoba metropolitan area. From November 1997 to October 1998, a total number of 65,000 children less than three years of age were assisted by the primary health network. Among them 7319 (11.2\%) of the children reported episodes of diarrhea and 253 (3.5\%) were referred because they demanded hospital admission as consequence of severe diarrhea.

Of the total hospitalized children, one hundred and thirty three patients $(52.6 \%)$ were enrolled in this study because each one fulfilled the following pre-established conditions: they were not derived from other hospital centers, had experienced less than five days of diarrheal evolution and the stool sample could be collected at the hospital admission day. Only a single specimen of whole stool from each child was obtained and stored at $-20{ }^{\circ} \mathrm{C}$ until tested for the presence of rotavirus, astrovirus and enteric adenovirus 40/41.

Diarrhea was defined as the occurrence of three or more unformed (loose or watery) stools within a 24 -hour period.

The patient's ages ranged from 1 to 35 months, with a mean of 11.7 months. The male to female ratio was 1.08 .

The authorities of the Hospital were notified about the nature and purpose of the study and their approval was obtained.

Enzyme Immune Assay for antigen virus detection: Assays of Group A human Rotavirus, Astrovirus and Enteric Adenovirus types 40/ 41 were obtained with the following commercial immunoassays: (Pathfinder Rotavirus Austin, Tx, IDEIA ${ }^{\mathrm{TM}}$ Astrovirus, DAKO diagnostics, Cambridgeshire, United Kingdom and Adenoclon type 40/ 41 Cambridge Biotech Corporation, Worcester, Mass.).

Group A Human Rotavirus antigen. The Pathfinder Rotavirus (Austin, Tx) assay uses rabbit polyclonal antirotavirus antibodies coated on polystyrene tubes as the solid phase, with a murine monoclonal antibody against VP6 conjugated to horseradish peroxidase used as detector. The assay was run according to the manufacturer's instructions. Results were spectrophotometrically read at $450 \mathrm{~nm}$. Cutoff values were calculated as specified in the package insert.

Astrovirus was detected with an enzyme immune assay kit (IDEIA ${ }^{\mathrm{TM}}$ DAKO diagnostics, Cambridgeshire, United Kingdom). The test combines a genus specific monoclonal and polyclonal antibodies which react with and detect known strains of human astroviruses in a solid phase immunoassay. The assay was run according to the manufacturer's instructions.

Enteric Adenovirus 40/41. Adenoclon Type 40/41 [Cambridge Biotech Corporation, Worcester, Mass.] was used. An aliquot fecal suspension was added to the microwells coated with a monoclonal antibody directed against the specific antigen group for all known human adenoviruses, and incubated simultaneously with anti-adenovirus types 40 and 41 monoclonal antibodies, conjugated to horseradish peroxidase, resulting in the adenovirus antigen being sandwiched between the solid phase and the enzyme conjugate. The assay was run according to the manufacturer's instructions. Spectrophotometric specimen assay with absorbance units (A450) equal to or higher than 0.150 were considered positive.

Statistical Methods: Statistical analysis of the data was made using the test of hypothesis for two proportionate to independent samples with normal aproximation ${ }^{1}$.

\section{RESULTS}

Epidemiology of severe viral diarrhea in hospitalized children: Hospital clinical reports and data on hospital admissions were used to estimate the number of hospitalization due to diarrhea illness in the Town Childhood Hospital, between November 1997 - October 1998. From a total of 3117 hospital admissions, $253(8.1 \%)$ corresponded to diarrhea. Of this, $133(52.6 \%)$ complied with the restrictive conditions to be involved in the study so, they were analyzed for viral detection. The characteristics of the population studied and the genera, age ranges and seasonal distribution of positive enteric viral samples are summarized in Table 1.

Enteric viruses were detected in 56/133 (42.1\%) of the stool samples studied. Three different viruses were identified: forty-seven $(35.3 \%)$ samples were tested positive for Goup A rotavirus, six (4.5\%) for astrovirus, two (1.5\%) for enteric adenovirus $40 / 41$ and only one dual infection of rotavirus and astrovirus was also revealed $(0.8 \%)$.

Rotavirus was detected in all age groups under study during all the periods analyzed although rotaviral infection showed higher rate of detection in the 6-11 (52\%) month age group as compared to 0-5 (19.2\%) $(\mathrm{p}<0.05), 12-23(29.2 \%)(\mathrm{p}<0.05)$ and $24-35(22.2 \%)(\mathrm{p}<0.05)$ month age groups; with highly seasonal peaks in the cooler semester, from April to September (cool semester $44.8 \%$ versus warm semester $25.6 \%, \mathrm{p}<0.05)$.

Astrovirus was detected among all age groups but, with nostatistically significant differences among the age groups studied ( $p>$ 0.05). The average age for astrovirus infection was 15 months, showing statistically significant differences between the average age for rotavirus infection $(8.2$ months $)(\mathrm{p}<0.05)$.

The astrovirus seasonal peak was like that of rotavirus, in the cooler semester (cool semester 6.0 vs $3.1 \%$ warm semester $\mathrm{p}<0.05$ ).

Adenovirus 40/41, which occurred in relatively small numbers, involved $1.5 \%$ of the stool samples studied. The small number of children infected with adenovirus 40/41 did not allow us to describe the age range 


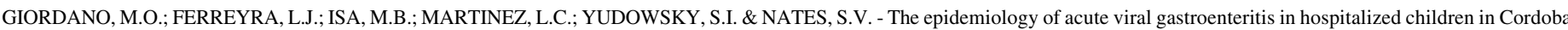
city, Argentina: an insight of disease burden. Rev. Inst. Med. trop. S. Paulo, 43(4):193-197, 2001.

Table 1

Frequency of rotavirus, astrovirus and adenovirus 40/41 in 133 children inpatients with diarrhea, by genera, age group and seasonal variations in Cordoba, Argentina. November 1997 - October 1998.

\begin{tabular}{|c|c|c|c|c|c|c|c|c|c|}
\hline \multirow[b]{2}{*}{ Viral Agents } & \multirow[b]{2}{*}{$\begin{array}{l}\text { Detection } \\
\text { rate }\end{array}$} & \multicolumn{2}{|c|}{ Genera } & \multicolumn{3}{|c|}{ Age range (months) } & \multirow[b]{2}{*}{$24-35$} & \multicolumn{2}{|c|}{ Seasonality } \\
\hline & & Male & Female & $0-5$ & $\begin{array}{l}6-11 \\
n(\%)\end{array}$ & $12-23$ & & $\begin{array}{c}\text { Cool semester } \\
\text { (April-September) }\end{array}$ & $\begin{array}{r}\text { Warm semester } \\
\text { (October/March) }\end{array}$ \\
\hline Rotavirus & $47(35.3)$ & $28(40.6)$ & $19(29.7)$ & $5(19.2)$ & $26(52.0)$ & $14(29.2)$ & $2(22.2)$ & $30(44.8)$ & $17(25.6)$ \\
\hline Astrovirus & $6(4.5)$ & $3(4.3)$ & $3(4.7)$ & $1(3.8)$ & $2(4.0)$ & $2(4.2)$ & $1(11.1)$ & $4(6.0)$ & $2(3.1)$ \\
\hline Adeno 40/41 & $2(1.5)$ & 一 & $2(3.1)$ & $1 \quad(3.8)$ & - & 一 & $1(11.1)$ & - & $2(3.1)$ \\
\hline Dual infection * & $1(0.8)$ & $1 \quad(1.5)$ & - & - & - & $1 \quad(2.1)$ & - & $1(1.5)$ & - \\
\hline Any virus ${ }^{\#}$ & $77(57.9)$ & $37(53.6)$ & $40(62.5)$ & $19(73.2)$ & $22(44.0)$ & $31(64.5)$ & $5(55.6)$ & $32(47.7)$ & $45(68.2)$ \\
\hline Total & $133(100)$ & $69(100)$ & $64(100)$ & $26(100)$ & $50 \quad(100)$ & $48 \quad(100)$ & $9(100)$ & $67(100)$ & $66(100)$ \\
\hline
\end{tabular}

* The dual infection consisted of one case of rotavirus and astrovirus. \# No rotavirus, astrovirus or adeno 40/41 was detected

and seasonal distribution of enteric adenovirus infection in in-patients with severe diarrhea.

According to our results, the proportional distribution of enteric viral agents detected in confined children under 36 months of age was as follows: rotavirus $84.0 \%$, astrovirus $10.7 \%$, enteric adenovirus $40 / 41$ $3.6 \%$ and dual rotavirus-astrovirus infection $1.7 \%$.

An insight of viral diarrheal disease burden in hospitalized children: Extrapolation of the hospital-based data to metropolitan data, on the basis of a cohort of 98,100 Cordobezan children 0-35 month-old, permitted an estimation of hospitalization rate for viral gastroenteritis for the whole population. The size of the children cohort at-risk was estimated by the 1991 National Census of Population and Housing ${ }^{12}$.

Epidemiologic data on the incidence of all diarrhea episodes and diarrhea cases requiring hospitalization were obtained from prospective studies performed in Córdoba city, and in Avellaneda, Buenos Aires, Argentina respectively. In a community-based study, with household surveillance of diarrhea episodes, done in a low socio-economic area of Córdoba city, the rate of gastroenteritis was 2.3 episodes/child/year in the first 35 months of life ${ }^{5}$. Besides, in a community-based study held in Avellaneda, Buenos Aires, a hospitalization rate of $3.9 \%$ for diarrhea was estimated ${ }^{8}$. Finally, we determined a viral enteric agent detection rate of $42.1 \%$ (56/133) among 0-35 month-old children admitted for severe diarrhea.

From the above data we estimated that 3,705 of the 98,100 Cordobezan children 0-35 months of age would be annually probably hospitalized for viral gastroenteritis-associated diarrhea (Fig. 1).

Rotavirus was the most commonly detected single etiological agent, responsible for $84.0 \%$ of the viral diarrheal cases, revealing a disproportionately high incidence of infection in infants against the other viral agents studied.
According to these estimates about one out of twenty-seven Cordobezan children in the cohort of 0-35 month-old would be annually admitted for viral diarrhea in Córdoba City $(98,100 / 3,705)$; one out of thirty-one for rotavirus infection $(98,100 / 3,112)$, one out of two hundred forty-seven for astrovirus infecction $(98,100 / 396)$ and one out of seven hundred thirty-two for adenovirus types 40/41 infection $(98,100 / 134)$.

\section{DISCUSSION}

Although the importance of viral diarrhea as a prime cause of morbidity and mortality in developing countries is well recognized ${ }^{13,17}$, there are very few reports that document the viral gastroenteritis disease burden in Latin America ${ }^{3-9-19}$.

Recently, GOMEZ et al. ${ }^{9}$ have published a review of available data on rotavirus detection reported by published and unpublished studies conduted in nine Argentine cities. These preliminary data showed that the rotavirus disease burden among Argentinian children is extensive, rendering an annual direct medical cost estimated at US\$27,7 million. The data reported represent a preliminary access of the magnitude of the problem in Argentina.

The present study that uses both a standard protocol for patient selection and virological assay of stool samples, involves the role of the three most important and recognized causes in the etiology of severe childhood diarrhea, that is Group A rotavirus, astrovirus and enteric adenovirus type $40 / 41^{6}$.

The sensitivity and specificity of the immunologic assays selected to detect the virus in question were 1.000 and 0.953 for enzyme immune assay Pathfinder Rotavirus (A. Cumino \& col.), 100.0 and $98.6 \%$ for IDEIA Astrovirus ${ }^{16}$ and $98.8 \%$ and $98 \%$ for Adenoclon type 40/41 (manufacture's data), respectively. The high sensitivities and specificities of the tests support the value of the data obtained. 


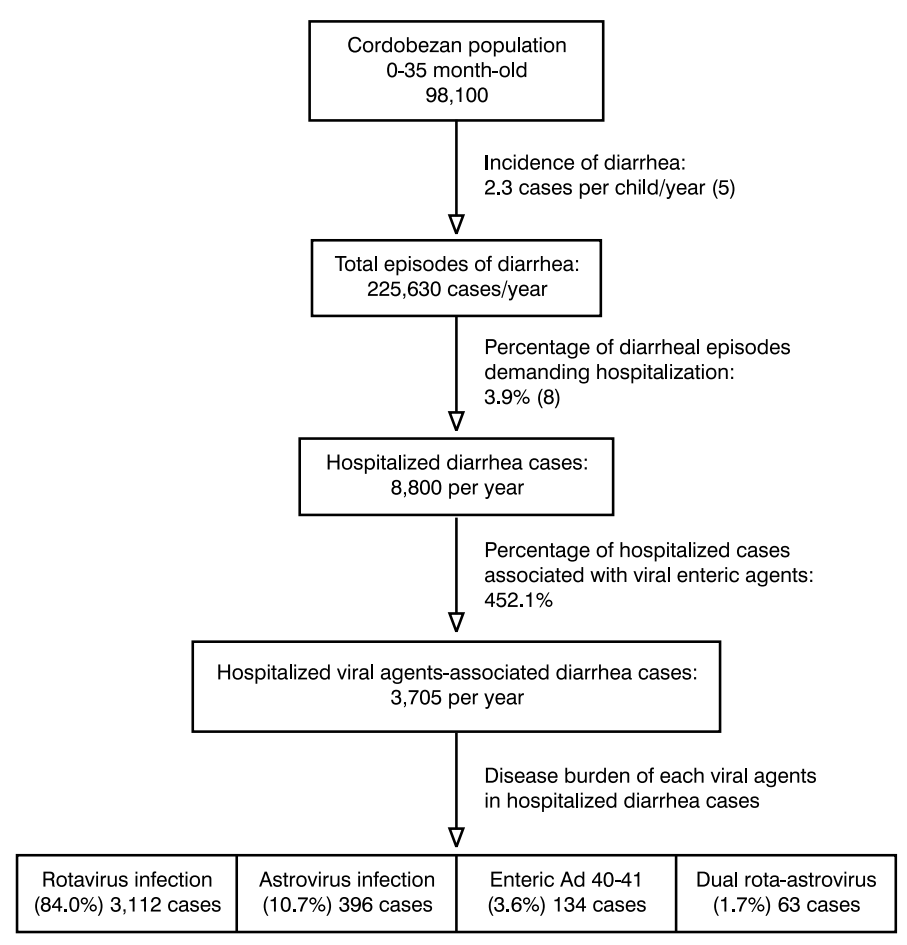

Fig. 1 - Annual estimate of the viral acute diarrheal disease burden on the hospital children admission and on the direct medical cost in Córdoba City, Argentina.

During our study, we estimated that rotavirus, astrovirus and adenovirus type 40/41, cause $1.8 \%$ (56/3117) of pediatric hospitalizations among infants under 3 years of age. Rotavirus was recognized as the most devastating cause of viral diarrhea in this population, accounting for approximately one third of cases of severe diarrhea requiring hospitalization (133/47) and $1.5 \%$ (47/3117) of total pediatric hospitalizations. So, our results show a high disproportion in the number of infants infected by rotavirus vs those infected by astrovirus or enteric adenovirus type 40 and 41 , yielding the astrovirus and adenovirus types 40/41 infection approximately one twenty-second and one sixty sixth part of cases of severe diarrhea requiring hospitalization (133/6 and 133/2).

Our report is the first to examine the epidemiology of astrovirus in hospitalized patients with acute gastroenteritis in Argentina. According to our results, astrovirus ranked second to rotavirus as a cause of hospital admission for childhood viral gastroenteritis. In spite of that, our results document that the occurrence of astrovirus detection in children with acute diarrhea severe enough to require hospital admission was as low as $4.5 \%$. Thus, astrovirus infection could be related to a mild diarrheal disease which would not require frequent hospitalization. These results are compatible with those published by other authors ${ }^{4,7}$.

We found a low rate of adenovirus 40/41 (1.5\%) in stools from hospitalized children with gastroenteritis compared to that for rotavirus and astrovirus. A limited number of adenovirus strains have been cause related to childhood diarrhea i.e., serotypes 40, 41 and $31^{17}$. Although several authors have reported that Ad 40 and 41 were isolated in the majority of diarrheal cases, Ad 31 was also associated ${ }^{15}$. Commercial enzyme immune assays kits are only available for the detection of Ad
40/41. Hence, the disease burden of the enteric adenoviruses has not been well defined, overlooking the role and significance of other strains in the global picture of chilhood diarrhea.

By and large, our study shows a good agreement with previous studies reporting detection rates of Group A rotavirus, astrovirus and adenovirus type 40 and 41 infections in hospitalized children with gastroenteritis $^{2,10,14,20}$.

Rotavirus has been widely acknowledged by several authors as a major cause of diarrhea in children worldwide ${ }^{6,18}$. Likewise, the mortality and hospitalization rates by rotavirus infection in developed versus developing countries are utterly distinctive (USA 300 deaths per year vs 2,000 children dying each day from rotavirus diarrhea respectively) ${ }^{18}$. This finding clearly shows that in addition to the infectious agent, many factors such as poorer nutritional status as well as inadequate sanitary conditions could explain the higher severity of rotaviral diarrhea. Because natural rotavirus infection reduces the occurrence and severity of subsequent episodes, rotavirus diarrhea might be controlled through vaccination. But the recently reported possible connection between intussusception and rotavirus vaccine use have to be clarified.

Besides, the implementation of a timely and accurate rotavirus diagnosis would provide the physician with useful information to prevent the unnecessary use of antibiotics and to identify infected individuals as potential sources of infection to others, specially in reference to nosocomial rotavirus diarrhea, which in term might add to costs of hospitalization and prolonged hospital stay by several days.

Therefore, improvement in socio-economic conditions, along with the introduction of an effective and safety vaccine and routine implementation of viral diagnosis have the potential to substantially reduce the occurrence of severe diarrhea.

\section{ACKNOWLEDGEMENTS}

This work has been supported by grants $1653 / 99$ and 163/99 from de Council of Science and Technology of Cordoba Province, Argentina (CONICOR) and the Science and Technology Secretary (SECYT), National University of Córdoba, Argentina.

The authors are grateful to Dr. Victor O. Giayetto for his Portuguese language assistance.

This work is dedicated to Silvia I. Medeot, Ph.D.

\section{RESUMO}

Epidemiologia da gastrenterite viral aguda em crianças hospitalizadas na cidade de Córdoba, Argentina: uma percepção ao impacto da doença

Dados a respeito do impacto das gastrenterites virais têm implicações importantes para o monitoraramento do impacto das políticas de saúde pública. O presente estudo, feito na cidade de Córdoba, Argentina, documenta a epidemiologia da diarréia viral severa como também o impacto que a mesma representa na admissão hospitalar de crianças. Pesquisou-se a presença de Rotavírus grupo A, Astrovírus e Adenovírus 
40/41 por ensaio imuno-enzimático em 133 amostras de fezes obtidas durante o período de novembro de 1997 a outubro de 1998, de crianças hospitalizadas por diarréia aguda. Os virus entéricos constituíram 42,1\% do total de casos de diarréia analisados. Encontraram-se Rotavírus Grupo A, Astrovírus, Adenovírus 40/41 e infecções mistas em 35,3; 4,5; 1,5 e $0,8 \%$ das amostrras estudadas, respectivamente. Observamos que uma de cada 27 crianças entre 0-35 meses de idade seria hospitalizada por ano devido a uma gastrenterite viral. O principal impacto da diarréia viral é representado pela infecção por Rotavírus, correspondendo a 84,0\% dos casos analisados e cerca de um terço das diarréias graves que precisam hospitalização em Córdoba, Argentina.

\section{REFERENCES}

1. BERENSON, M.L. \& LEVINE D.M. - Estadistica para la administración y economia. 6. ed. New York, Prentice Hall Hispanoamericano, 1997. p. 605-658

2. BON, F.; FASCIA, P.; DAUVERGNE, M. et al. - Prevalence of group A rotavirus, human calicivirus, astrovirus, and adenovirus type 40 and 41 infections among children with acute gastroenteritis in Dijon, France. J. clin. Microbiol., 37: 3055-3058, 1999.

3. CAMA, R.I.; PARASHAR, U.D.; TAYLOR, D.N. et al. - Enteropathogens and other factors associated with severe disease in children with acute watery diarrhea in Lima, Peru. J. infect. Dis., 179: 1139-1144, 1999.

4. CRUZ, J.R.; BARTLETT, A.V.; HERMANN, J.E. et al. - Astrovirus-associated diarrhea among Guatemalan ambulatory rural children. J. clin. Microbiol., 30: 1140-1144, 1992.

5. DEPETRIS, A.R.; BARATELLI, S. \& GATTI, A. - In: REUNION CIENTÍFICA DE LA SOCIEDAD ARGENTINA DE INVESTIGACIÓN CLÍNICA, 23, 1988.

6. GLASS, R.I. \& KILGORE, P.E. - Etiology of acute viral gastroenteritis. Diarr. Dis., 38: 39-54, 1997.

7. GLASS, R.I.; NOEL, J.; MITCHELL, D. et al. - The changing epidemiology of astrovirusassociated gastroenteritis: a review. Arch. Virol. Suppl., 12: 287-300, 1996.

8. GOMEZ, J.; BERCOVICH, J.; BISCOTI, E. et al. - Diarrea por rotavirus: estudio prospectivo de 49 familias del partido de Avellaneda, Provincia de Buenos Aires. Arch. argent. Pediat., 85: 139-149, 1987.
9. GOMEZ, J.A.; NATES, S.; CASTAGNARO, N.R. et al. - Anticipating rotavirus vaccines: review of epidemiologic studies of rotavirus diarrhea in Argentina. Rev. Panamer. Salud publ., 3: 69-78, 1998

10. GRIMWOOD, K.; CARZINO, R.; BARNES, G.L. \& BISHOP, R.F. - Patients with enteric adenovirus gastroenteritis admitted to an Australian pediatric teaching hospital from 1981 to 1992. J. clin. Microbiol., 33: 131-136, 1995.

11. HERRMANN, J.E. \& BLACKLOW, N.R. - Enteric adenoviruses. In: BLASER, M.J.; SMITH, P.D.; RAVDIN, J.I.; GREENBERG, H.B. \& GUERRANT, R.L., ed. Infections of the gastrointestinal tract. New York, Raven Press, 1995. p. 1047 1053 .

12. INSTITUTO NACIONAL DE ESTADÍSTICA Y CENSOS - Censo Nacional de población y vivienda. Buenos Aires, INDEC 101, 1991.

13. KAPIKIAN, A.Z. - Overview of viral gastroenteritis. Arch. Virol. Suppl., 12: 7-19, 1996

14. KIM, K.H.; YANG, J.M.; JOO, S.I. et al. - Importance of rotavirus and adenovirus types 40 and 41 in acute gastroenteritis in Korean children. J. clin. Microbiol., 28: 2279 2284,1990

15. KRADJEN, M.; BROWN, M.; PETRASECK, A. \& MIDDLETOM, P.J. - Clinical features of adenovirus enteritis: a review of 127 cases. Pediat. infect. Dis. J., 9: 636-641, 1990

16. MCIVER, C.J.; PALOMBO, E.A.; DOULTREE, J.C. et al. - Detection of astrovirus gastroenteritis in children. J. virol. Meth., 84: 99-105, 2000

17. MIDDLETON, P.J. - Viruses that multiply in the gut and cause endemic and epidemic gastroenteritis. Clin. diagn. Virol., 6: 93-101, 1996.

18. PARASHAR, U.D.; BRESEE, J.S.; GENTSCH, J.R. \& GLASS, R.I. - Rotavirus. Emerg. infect. Dis., 4: 561-570, 1998.

19. PEREZ-SCHAEL, I. - The impact of rotavirus disease in Venezuela. J. infect. Dis., 174(suppl. 1): S19-S21, 1996.

20. QIAO, H.; NILSSON, M.; ABREU, E.R. et al. - Viral diarrhea in children in Beijing, China. J. med. Virol., 57: 390-396, 1999.

Received: 02 March 2001

Accepted: 27 April 2001 